\title{
Planococcus stackebrandtii sp. nov., isolated from a cold desert of the Himalayas, India
}

\author{
Correspondence \\ T. Chakrabarti \\ tapan@imtech.res.in
}

\author{
S. Mayilraj, ${ }^{1}$ G. S. Prasad, ${ }^{1}$ K. Suresh, ${ }^{2}$ H. S. Saini, ${ }^{3}$ S. Shivaji ${ }^{2}$ \\ and T. Chakrabarti ${ }^{1}$ \\ 'Microbial Type Culture Collection \& Gene Bank (MTCC), Institute of Microbial Technology, \\ Chandigarh, 160 036, India \\ ${ }^{2}$ Centre for Cellular and Molecular Biology (CCMB), Hyderabad, 500 007, India \\ ${ }^{3}$ Guru Nanak Dev University (GNDU), Amritsar, 143 005, India
}

The taxonomic position of a bacterium isolated from a cold desert of the Himalayas, India, was analysed by using a polyphasic approach. The isolated strain, designated $\mathrm{K} 22-03^{\top}$, had phenotypic characteristics that matched those of the genus Planococcus and it represents a novel species. The almost-complete 16S rRNA gene sequence (1464 bases) of the novel strain was compared with those of previously studied Planococcus type strains and confirmed that the strain belongs to the genus Planococcus. 16S rRNA gene sequence analysis indicated that strain $\mathrm{K} 22-03^{\top}$ differs from all other species of Planococcus by at least $2 \cdot 5 \%$. DNA-DNA hybridization showed that it had low genomic relatedness with Planomicrobium mcmeekinii (MTCC $3704^{\top}, 23 \%$ ), Planococcus psychrophilus (MTCC $3812^{\top}, 61 \%$ ), Planococcus antarcticus (MTCC $3854^{\top}, 45 \%$ ) and Planomicrobium okeanokoites (MTCC $3703^{\top}, 51 \%$ ), the four species with which it was most closely related based on 16S rRNA gene sequence analysis (97-97.5\% similarity). Therefore, strain $\mathrm{K} 22-03^{\top}$ should be recognized as a novel species, for which the name Planococcus stackebrandtii sp. nov. is proposed. The type strain is K22-03 ${ }^{\top}\left(=\right.$ MTCC $6226^{\top}=$ DSM $\left.16419^{\top}=J_{C M} 12481^{\top}\right)$.
The genus Planococcus was first established over 100 years ago by Migula (1894) and was later emended by Nakagawa et al. (1996). At present the genus comprises eight recognized species, Planococcus citreus (Migula, 1894), Planococcus kocurii (Hao \& Komagata, 1985), Planococcus alkanoclasticus (Engelhardt et al., 2001), Planococcus antarcticus and Planococcus psychrophilus (Reddy et al., 2002), Planococcus maritimus (Yoon et al., 2003), Planococcus rifietoensis (Romano et al., 2003) and Planococcus maitriensis (Alam et al., 2003).

A bacterial strain, designated $\mathrm{K} 22-03^{\mathrm{T}}$, was isolated from a cold desert of the Himalayas, northern India, using a dilution plating technique on trypticase soy agar (TSA; Himedia, India) and maintained as glycerol stocks at $-70{ }^{\circ} \mathrm{C}$. The reference strains of Planomicrobium mcmeekinii (MTCC $3704^{\mathrm{T}}$ ), Planomicrobium okeanokoites (MTCC $3703^{\mathrm{T}}$ ), Planococcus psychrophilus (MTCC 3812 ${ }^{\mathrm{T}}$ ) and Planococcus antarcticus (MTCC $3854^{\mathrm{T}}$ ) were obtained

Published online ahead of print on 13 August 2004 as DOI 10.1099/ ijs.0.63290-0.

The GenBank/EMBL/DDBJ accession number for the 16S rRNA gene sequence of Planococcus stackebrandtii strain $\mathrm{K} 22-03^{\top}$ is $\mathrm{AY} 437845$. from the Microbial Type Culture Collection (MTCC), Chandigarh, India.

Strain $\mathrm{K} 22-03^{\mathrm{T}}$ and the three closely related organisms given above were grown on TSA and tested for morphological, physiological and chemotaxonomic characteristics. These four strains were also checked for various biochemical properties, such as reaction to oxidase and catalase, aerobic or anaerobic growth, and hydrolysis of Tween 20, starch, casein and gelatin. Whole-cell sugars and amino acids were determined by TLC as described by Staneck \& Roberts (1974). Phospholipids and menaquinones were extracted and analysed using the methods described by Minnikin \& Goodfellow (1976) and Minnikin et al. (1978). Fatty acid methyl esters were extracted and analysed as described by Pandey et al. (2002).

The chromosomal DNA of strain $\mathrm{K} 22-03^{\mathrm{T}}$ was isolated according to the procedure described by Rainey et al. (1996). The 16S rRNA gene was amplified with primers 8-27f (5'-AGAGTTTGATCCTGGCTCAG-3') and 1500r $\left(5^{\prime}\right.$-AGAAAGGAGGTGATCCAGGC-3'). The amplified DNA fragment was separated on a $1 \%$ agarose gel, eluted from the gel and purified using the Qiaquick gel extraction kit (Qiagen). The purified PCR product was sequenced with four forward and three reverse primers: 8-27f 
(5'-AGAGTTTGATCCTGGCTCAG-3'), 357f (5'-CTCCTACGGGAGGCAGCAG-3'), 704f (5' -TAGCGGTGAAATGCGTAGA-3'), 1114f (5'-GCAACGAGCGCAACC-3'), 685r (5'-TCTACGCATTTCACCGCTAC-3'), 1110r (5' GGGTTGCGCTCGTTG-3') and 1500r (5'-GAAAGGAGGTGATCCAGGC-3') (Escherichia coli numbering system). The rRNA gene sequence was determined by the dideoxy chain-termination method using the BigDye terminator kit and an ABI 310 Genetic Analyser (Applied Biosystems). DNA-DNA hybridization was performed by the membrane filter method (Tourova \& Antonov, 1987) as described by Shivaji et al. (1992) and Reddy et al. (2000).

The 16S rRNA gene sequence of strain $\mathrm{K} 22-03^{\mathrm{T}}$ generated here (1464 bases) was aligned with those of other Planococcus and Planomicrobium species retrieved from the GenBank database. A sequence similarity search was performed on these using BLASTN (Altschul et al., 1997). Sequences of closely related taxa were retrieved and aligned using the CLUSTAL_X program (Thompson et al., 1997); the alignment was corrected manually. For the neighbourjoining analysis (Saitou \& Nei, 1987), distances between sequences were calculated using Kimura's two-parameter model (Kimura, 1980). Bootstrap analysis was performed to assess the confidence limits of the branching (Felsenstein, 1985).

Colonies grown on TSA were orange-coloured and about 1-2 $\mathrm{mm}$ in diameter, circular, smooth and convex. Biochemical and chemotaxonomic characteristics confirmed strain K22- $03^{\mathrm{T}}$ to be a member of the genus Planococcus. Test reactions are given in Table 1 together with those of three closely related taxa. Strain $\mathrm{K} 22-03^{\mathrm{T}}$ differs from these three closely related species in acid production from different sugars. The diagnostic cell-wall amino acid is L-lysine and the diagnostic cell-wall sugars are D-glucose and D-ribose. The fatty acid profile of strain $\mathrm{K} 22-03^{\mathrm{T}}$ is similar to those of the three closely related species except for the presence of $\mathrm{C}_{17: 0}$ and $\mathrm{C}_{16: 1} \omega 11 \mathrm{c}$ in $\mathrm{K} 22-03^{\mathrm{T}}$ (Table 2). The major menaquinones are MK-7 and MK-8 and the strain has a type II phospholipid pattern. The DNA G $+C$ content of strain $\mathrm{K} 22-03^{\mathrm{T}}$ is $40 \mathrm{~mol} \%$. To determine the phylogenetic position of strain $\mathrm{K} 22-03^{\mathrm{T}}$, the 16S rRNA gene sequence was compared with those of type strains of species of the genera Planococcus and Planomicrobium retrieved from the GenBank database. Sequence similarity of $\mathrm{K} 22-03^{\mathrm{T}}$ with the genera Planococcus and Planomicrobium ranges from $95 \cdot 4$ to $97 \cdot 6 \%$. A rooted

Table 1. Comparison of the phenotypic characteristics of strain $K 22-03^{\top}$ (1) with those of the type strains of Planomicrobium okeanokoites (2), Planomicrobium mcmeekinii (3) and Planococcus psychrophilus (4)

None of the four micro-organisms produces spores, hydrolyses starch or is acid-fast. They all produce acid from fructose and galactose, but not from rhamnose or salicin. They all produce an orange pigment. +, Positive; -, negative; $\mathrm{W}$, weakly positive.

\begin{tabular}{|c|c|c|c|c|}
\hline Tests & 1 & 2 & 3 & 4 \\
\hline Gram's staining & + & +/Variable & + & + \\
\hline Cell shape & Cocci & Cocci/rods & Cocci/rods & Rods \\
\hline Cell arrangement & Tetrads & Tetrads & Tetrads & Single \\
\hline Growth temperature $\left({ }^{\circ} \mathrm{C}\right)$ & $15-30$ & $20-37$ & $0-37$ & $0-30$ \\
\hline Acid from glucose: & - & - & + & - \\
\hline Xylose & - & - & $+\mathrm{W}$ & - \\
\hline Lactose & + & - & $+\mathrm{w}$ & - \\
\hline Arabinose & - & - & + & - \\
\hline Mannitol & - & + & - & - \\
\hline myo-Inositol & - & - & - & + \\
\hline Raffinose & + & - & + & - \\
\hline Sucrose & + & + & + & - \\
\hline $\mathrm{G}+\mathrm{C}$ content of DNA $(\mathrm{mol} \%)$ & 40 & $46 \cdot 3$ & 35 & $44 \cdot 5$ \\
\hline Catalase & $+\mathrm{W}$ & + & + & $+\mathrm{w}$ \\
\hline Oxidase & - & + & - & + \\
\hline Nitrate reduction & - & - & + & - \\
\hline \multicolumn{5}{|l|}{ Growth in: } \\
\hline $7 \% \mathrm{NaCl}$ & + & - & + & + \\
\hline $8 \% \mathrm{NaCl}$ & - & - & + & + \\
\hline Hydrolysis of casein & - & + & + & - \\
\hline Hydrolysis of gelatin & $+\mathrm{w}$ & + & + & - \\
\hline Hydrolysis of Tween 20 & + & - & - & + \\
\hline
\end{tabular}


Table 2. Comparison of the fatty acid profile (\%) of strain $\mathrm{K} 22-03^{\top}$ (1) with those of the type strains of Planomicrobium okeanokoites (2), Planomicrobium mcmeekinii (3) and Planococcus psychrophilus (4)

\begin{tabular}{|c|c|c|c|c|}
\hline Fatty acid & 1 & 2 & 3 & 4 \\
\hline \multicolumn{5}{|c|}{ Straight-chain fatty acids } \\
\hline $\mathrm{C}_{15: 0}$ & $5 \cdot 49$ & $1 \cdot 73$ & $4 \cdot 53$ & Absent \\
\hline $\mathrm{C}_{16: 0}$ & Absent & $1 \cdot 1$ & $1 \cdot 1$ & $2 \cdot 24$ \\
\hline $\mathrm{C}_{17: 0}$ & $2 \cdot 07$ & Absent & Absent & Absent \\
\hline \multicolumn{5}{|l|}{ Branched fatty acids } \\
\hline iso- $\mathrm{C}_{14: 0}$ & $4 \cdot 67$ & $14 \cdot 56$ & $6 \cdot 18$ & $5 \cdot 33$ \\
\hline iso- $\mathrm{C}_{15: 0}$ & $2 \cdot 85$ & $5 \cdot 31$ & $4 \cdot 53$ & $5 \cdot 76$ \\
\hline anteiso- $\mathrm{C}_{15: 0}$ & $49 \cdot 83$ & $30 \cdot 44$ & $49 \cdot 46$ & $53 \cdot 51$ \\
\hline iso- $\mathrm{C}_{16: 0}$ & $5 \cdot 65$ & $18 \cdot 19$ & $6 \cdot 41$ & $7 \cdot 06$ \\
\hline iso- $\mathrm{C}_{17: 0}$ & $2 \cdot 84$ & $3 \cdot 50$ & Absent & Absent \\
\hline anteiso- $\mathrm{C}_{17: 0}$ & $4 \cdot 55$ & $3 \cdot 93$ & $5 \cdot 40$ & $4 \cdot 04$ \\
\hline iso- $\mathrm{C}_{17: 1} \omega 10 c$ & $1 \cdot 74$ & Absent & $4 \cdot 33$ & $3 \cdot 38$ \\
\hline iso- $\mathrm{C}_{18: 0}$ & Absent & $2 \cdot 26$ & Absent & Absent \\
\hline \multicolumn{5}{|c|}{ Unsaturated fatty acids } \\
\hline $\mathrm{C}_{16: 1} \omega 7 c$ alcohol & $8 \cdot 53$ & $15 \cdot 94$ & $12 \cdot 51$ & $10 \cdot 05$ \\
\hline $\mathrm{C}_{16: 1} \omega 11 c$ & $1 \cdot 74$ & Absent & Absent & Absent \\
\hline Summed feature $4^{*}$ & $8 \cdot 64$ & $2 \cdot 33$ & $11 \cdot 17$ & $8 \cdot 63$ \\
\hline
\end{tabular}

${ }^{*}$ Summed feature 4 represents iso-iso- $\mathrm{C}_{17: 1}$ I and/or anteiso-iso$\mathrm{C}_{17: 1} \mathrm{~B}$, which could not be separated by GC with the MIDISherlock Identification System.

phylogenetic tree based on the neighbour-joining method is shown in Fig. 1. Strain K22- $03^{\mathrm{T}}$ formed a separate line among the genus Planococcus. Strain K22-0 $3^{\mathrm{T}}$ is moderately related to 'Planococcus psychrotoleratus' $(97.6 \%)$, Planomicrobium okeanokoites $(97 \cdot 5 \%)$ Planococcus psychrophilus $(97 \cdot 4 \%)$ and Planococcus antarcticus $(97 \cdot 0 \%)$, and distantly related to Planomicrobium momeekinii $(96 \cdot 8 \%)$, Planococcus maritimus (96.6\%), Planococcus alkanoclasticus (96.5\%), Planococcus maitriensis $(96 \cdot 3 \%)$, Planococcus rifietoensis (96.2\%), Planococcus citreus (95.7\%) and Planococcus kocurii $(95 \cdot 4 \%)$. Genomic relatedness, as shown by DNA-DNA hybridization, of strain K22-03 ${ }^{\mathrm{T}}$ with Planococcus momeekinii is $23 \%$, with Planococcus psychrophilus is $61.0 \%$, with Planococcus antarcticus is $45 \%$ and with Planomicrobium okeanokoites is $51 \cdot 0 \%$. At the level of $3-4 \%$ dissimilarity in $16 \mathrm{~S}$ rRNA gene sequences, members of other species of the genus can be excluded from DNA-DNA hybridization studies (Stackebrandt \& Goebel, 1994). This conclusion is confirmed by DNA dissimilarity values distinctly lower than $70 \%$ (Wayne et al., 1987) obtained from two members each of the genera Planococcus and Planomicrobium. On the basis of morphology, growth characteristics, biochemical and chemotaxonomic characteristics, molecular systematic studies including $16 \mathrm{~S}$ rRNA gene sequence analysis, DNA G $+\mathrm{C}$ content and DNADNA hybridization analysis, strain $\mathrm{K} 22-03^{\mathrm{T}}$ is considered to represent a novel species of the genus Planococcus, for which the name Planococcus stackebrandtii sp. nov. is proposed.

\section{Description of Planococcus stackebrandtii sp. nov.}

Planococcus stackebrandtii (sta.cke.brand.ti'i. N.L. gen. n. stackebrandtii of Stackebrandt, to honour Erko Stackebrandt, a German microbiologist, for his valuable contributions to microbial taxonomy and molecular systematics).

Cells are Gram-positive, aerobic, non-spore-forming, motile and coccoid, occurring in pairs and in groups. Colonies on TSA are orange, opaque, smooth, convex, circular, entire and 1-2 $\mathrm{mm}$ in diameter. Growth occurs at $15-30{ }^{\circ} \mathrm{C}$ (optimum $25^{\circ} \mathrm{C}$ ) and at $\mathrm{pH} 5 \cdot 6-11 \cdot 0$. Can tolerate up to $7 \% \mathrm{NaCl}$. Positive for citrate utilization, Tween 20 hydrolysis, gelatin hydrolysis, ornithine decarboxylase and catalase, but negative for oxidase, casein hydrolysis, starch hydrolysis, urease production, methyl red and VogesProskauer reaction, hydrogen sulfide production, nitrate

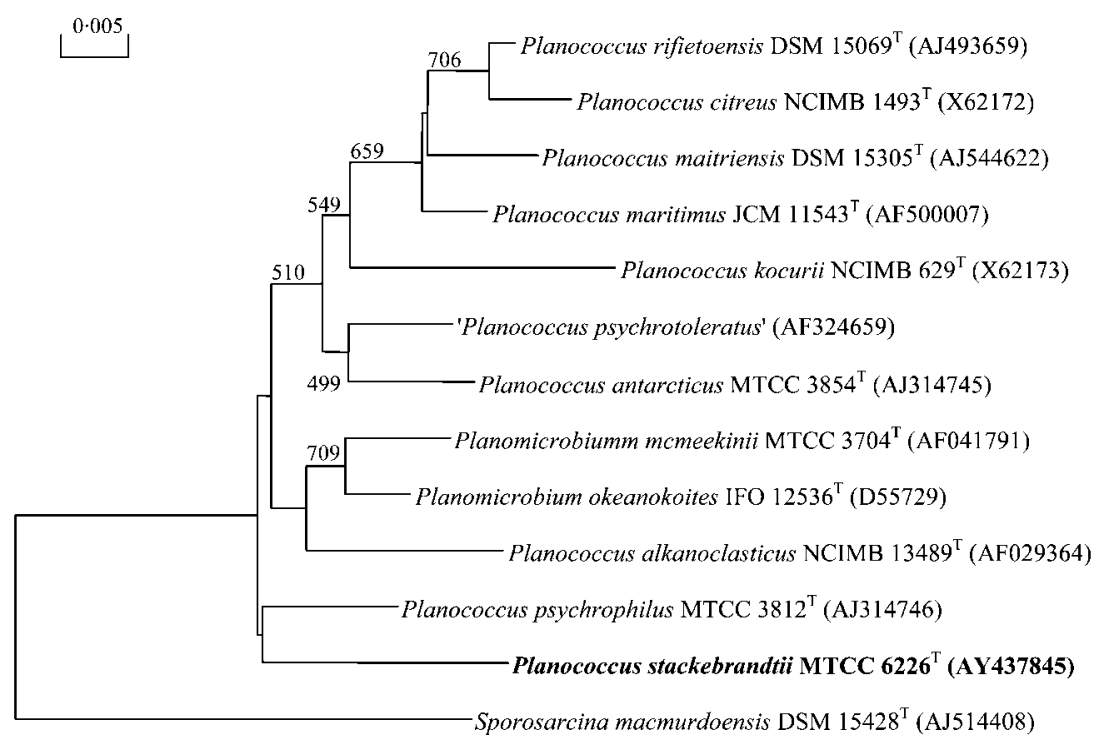

Fig. 1. Neighbour-joining tree based on 16S rRNA gene (1464 bases) sequences showing the phylogenetic relationship of Planococcus stackebrandtii strain $\mathrm{K}_{2} 2-03^{\top}$ with other related species of the genera Planococcus and Planomicrobium. Bootstrap values (expressed as percentage of 1000 replications) greater than $50 \%$ are given at the nodes. Bar, $0.5 \%$ sequence variation. 
reduction, arginine dihydrolase and lysine decarboxylase. No gas is produced from glucose medium. Acid is produced from galactose, fructose, lactose, raffinose and sucrose, but not from glucose, arabinose, mannitol, xylose, myo-inositol, rhamnose or salicin. As sole nitrogen source, it is negative for histidine, phenylalanine, valine, cysteine, hydroxy proline, arginine and serine. Cell-wall peptidoglycan contains L-lysine; cell-wall sugars are Dglucose and D-ribose. MK-7 and MK-8 are the major menaquinones. DNA $\mathrm{G}+\mathrm{C}$ content is $40 \mathrm{~mol} \%$. Predominant fatty acids are anteiso- $\mathrm{C}_{15: 0}$ and $\mathrm{C}_{16: 1} \omega 7 c$ alcohol, with minor amounts of $\mathrm{C}_{15: 0}, \mathrm{C}_{17: 0}$ and $\mathrm{C}_{16: 1} \omega 11 \mathrm{c}$. Phospholipid is of type II, which has the predominant polar lipids phosphatidylglycerol, diphosphatidylglycerol and phosphatidylethanolamine.

The type strain, K22-03 ${ }^{\mathrm{T}}\left(=\right.$ MTCC $6226^{\mathrm{T}}=$ DSM $16419^{\mathrm{T}}$ $=\mathrm{JCM} 12481^{\mathrm{T}}$ ), was isolated from soil, $0.45 \mathrm{~m}$ below an ice glacier, at $4200 \mathrm{~m}$ elevation, Kibber village, Spiti valley, Himachal Pradesh, India.

\section{Acknowledgements}

We are grateful to Dr Sanjay Kumar, IHBT, Palampur, for his help in sample collection and Dr K. Ganesan for his help with DNA sequencing. We acknowledge Professor Erko Stackebrandt for critical reading of the manuscript. We would like to thank Mr Malkit Singh for his excellent technical assistance. Financial assistance from CSIR and DBT, Government of India, is acknowledged. This is IMTECH communication number $11 / 2004$.

\section{References}

Alam, S. I., Singh, L., Dube, S., Reddy, G. S. N. \& Shivaji, S. (2003). Psychrophilic Planococcus maitriensis sp.nov. from Antarctica. Syst Appl Microbiol 26, 505-510.

Altschul, S. F., Madden, T. L., Schaffer, A. A., Zhang, J., Zhang, Z., Miller, W. \& Lipman, D. J. (1997). Gapped BLAST and PSI-BLAST: a new generation of protein database search programs. Nucleic Acids Res 25, 3389-3402.

Engelhardt, M. A., Daly, K., Swannell, R. P. J. \& Head, I. M. (2001). Isolation and characterization of a novel hydrocarbon-degrading, Gram-positive bacterium, isolated from intertidal beach sediment, and description of Planococcus alkanoclasticus sp. nov. J Appl Microbiol 90, 237-247.

Felsenstein, J. (1985). Confidence limits on phylogenies: an approach using the bootstrap. Evolution 39, 783-791.

Hao, M. V. \& Komagata, K. (1985). A new species of Planococcus, P. kocurii isolated from fish, frozen foods, and fish curing brine. J Gen Appl Microbiol 31, 441-455.

Kimura, M. (1980). A simple method for estimating evolutionary rates of base substitutions through comparative studies of nucleotide sequences. J Mol Evol 16, 111-120.

Migula, W. (1894). Uber ein neues System der Bakterien. Arb Bakteriol Inst Karlsruhe 1, 235-238.

Minnikin, D. E. \& Goodfellow, M. (1976). Lipid composition in the classification and identification of Nocardia and related taxa. In The
Biology of the Nocardiaceae, pp. 160-219. Edited by M. Goodfellow, G. H. Brownell \& J. A. Serrano. London: Academic Press.

Minnikin, D. E., Collins, M. D. \& Goodfellow, M. (1978). Menaquinone patterns in the classification of nocardioform and related bacteria. Zentbl Bakteriol Parasitenkd Infektionskr U HygI Abt 1 Suppl. 6, 85-90.

Nakagawa, Y., Sakane, T. \& Yokota, A. (1996). Emendation of the genus Planococcus and transfer of Flavobacterium okeanokoites Zobell and Upham 1944 to the genus Planococcus as Planococcus okeanokoites comb. nov. Int J Syst Bacteriol 46, 866-870.

Pandey, K. K., Mayilraj, S. \& Chakrabarti, T. (2002). Pseudomonas indica sp. nov., a novel butane-utilizing species. Int $J$ Syst Evol Microbiol 52, 1559-1567.

Rainey, F. A., Ward-Rainey, N., Kroppenstedt, R. M. \& Stackebrandt, E. (1996). The genus Nocardiopsis represents a phylogenetically coherent taxon and a distinct actinomycete lineage: proposal of Nocardiopsaceae fam. nov. Int J Syst Bacteriol 46, 1088-1092.

Reddy, G. S. N., Aggarwal, R. K., Matsumoto, G. I. \& Shivaji, S. (2000). Arthrobacter flavus sp. nov., a psychrophilic bacterium isolated from a pond in McMurdo Dry Valley, Antarctica. Int J Syst Evol Microbiol 50, 1553-1561.

Reddy, G. S. N., Prakash, J. S. S., Vairamani, M., Prabhakar, S., Matsumoto, G. I. \& Shivaji, S. (2002). Planococcus antarcticus and Planococcus psychrophilus spp. nov. isolated from cyanobacterial mat samples collected from ponds in Antarctica. Extremophiles 6, 253-261.

Romano, I., Giordano, A., Lama, L., Nicolaus, B. \& Gambacorta, A. (2003). Planococcus rifietensis sp. nov., isolated from algal mat collected from a sulfurous spring in Campania (Italy). Syst Appl Microbiol 26, 357-366.

Saitou, N. \& Nei, M. (1987). The neighbor-joining method: a new method for reconstructing phylogenetic trees. Mol Biol Evol 4 406-425.

Shivaji, S., Ray, M. K., Rao, N. S., Saisree, L., Jagannadham, M. V., Kumar, G. S., Reddy, G. S. N. \& Bhargava, P. M. (1992). Sphingobacterium antarcticus sp. nov., a psychrotrophic bacterium from the soils of Schirmacher Oasis, Antarctica. Int J Syst Bacteriol 42, 102-106.

Stackebrandt, E. \& Goebel, B. M. (1994). Taxonomic note: a place for DNA-DNA reassociation and 16S rRNA sequence analysis in the present species definition in bacteriology. Int J Syst Bacteriol 44, 846-849.

Staneck, J. L. \& Roberts, G. D. (1974). Simplified approach to identification of aerobic actinomycetes by thin-layer chromatography. Appl Microbiol 28, 226-231.

Thompson, J. D., Gibson, T. J., Plewniak, F., Jeanmougin, F. \& Higgins, D. G. (1997). The CLUSTAL_X Windows interface: flexible strategies for multiple sequence alignment aided by quality analysis tools. Nucleic Acids Res 25, 4876-4882.

Tourova, T. P. \& Antonov, A. S. (1987). Identification of microorganisms by rapid DNA-DNA hybridization. Methods Microbiol 19, 333-355.

Wayne, L. G., Brenner, D. J., Colwell, R. R. \& 9 other authors (1987). International Committee on Systematic Bacteriology. Report of the ad hoc committee on reconciliation of approaches to bacterial systematics. Int J Syst Bacteriol 37, 463-464.

Yoon, J.-H., Weiss, N., Kang, K. H., Oh, T.-K. \& Park, Y.-H. (2003). Planococcus maritimus sp. nov., isolated from sea water of a tidal flat in Korea. Int J Syst Evol Microbiol 53, 2013-2017. 